GRASAS Y ACEITES 65 (4)

October-December 2014, e048

ISSN-L: 0017-3495

doi: http://dx.doi.org/10.3989/gya.0460141

\title{
A comparative study of the fatty acid profiles in commercial sheep cheeses
}

\author{
C. Aguilar ${ }^{1}$, P. Toro-Mujica ${ }^{1}$, E. Vargas-Bello-Pérez ${ }^{1,}$, R. Vera ${ }^{1}$, C. Ugalde $^{1}$, S. Rodríguez $^{1}$ and I. Briones ${ }^{2}$ \\ ${ }^{1}$ Departamento de Ciencias Animales, Facultad de Agronomía e Ingeniería Forestal, Pontificia Universidad \\ Católica de Chile, Santiago, Chile. Casilla-306. P. O. Box 6904411 \\ ${ }^{2}$ Fondo para la Innovación Agraria, Ministerio de Agricultura, Loreley 1582, La Reina, Santiago, Chile \\ ${ }^{\square}$ Corresponding author: evargasb@uc.cl.
}

Submitted: 14 April 2014; Accepted: 10 July 2014

SUMMARY: The present study was carried out to characterize the FA profile of sheep cheese marketed in Chile. Fifty-eight cheeses were collected from supermarkets of 5 different Chilean cities including 34 sheep cheeses, 7 from goat's milk, 11 from cow's milk, 4 from a mixture of sheep, goat and cow's milk and 2 from a mixture of sheep and cow's milk. Compared to the cow and goat cheese $\left(3.4\right.$ and $\left.2.5 \mathrm{~g} \cdot 100 \mathrm{~g}^{-1}\right)$, the sheep cheese $\left(3.8 \mathrm{~g} \cdot 100 \mathrm{~g}^{-1}\right)$ contained higher contents of $\mathrm{C} 18: 1 \mathrm{t}$. The saturated and polyunsatured FA contents were greater in goat cheese than in sheep and cow cheese. The $\mathrm{n} 6 / \mathrm{n} 3$ ratio was greater in goat (6.1) cheese than in sheep and cow cheese (3.8 and 5.2). The atherogenicity index was unaffected by cheese type, however, the thrombogenic index was lower in sheep cheese (2.8) than in goat and cow cheese (3.1 and 2.9). The n6/n 3 ratio and thrombogenic index were lower in Chilean sheep cheese than in those imported from Europe. The fatty acid profile of cheese can be used to differentiate animal species from which the cheese is made and to some extent the geographical origin that may give some insight as to animal feed and production management.

\section{KEYWORDS: Cheese; Fatty acids; Milk; Sheep}

RESUMEN: Estudio comparativo del perfil de ácidos grasos de quesos de oveja comerciales. Este estudio fue llevado a cabo para caracterizar el perfil de AG de quesos de oveja que se comercializan en Chile. Cincuenta y ocho quesos fueron recogidos de supermercados de 5 ciudades de Chile de los cuales 34 fueron de oveja, 7 de cabra, 11 de vaca, 4 de mezcla de leche de oveja, cabra y vaca y 2 de mezcla de leche de oveja y vaca. Comparado con quesos de vaca y cabra $\left(3.4\right.$ y $\left.2.5 \mathrm{~g} \cdot 100 \mathrm{~g}^{-1}\right)$, los quesos de oveja $\left(3.8 \mathrm{~g} \cdot 100 \mathrm{~g}^{-1}\right)$ presentaron mayor contenido de C18:1t. Los AG saturados y poliinsaturados tuvieron concentraciones más altas en los quesos de cabra que en los quesos de oveja y vaca. La relación n6/n3 fue más alta en quesos de cabra (6.1) que en quesos de oveja y vaca (3.8 y 5.2). El índice aterogénico no fue afectado por el tipo de queso, sin embargo, el índice trombogénico fue menor en quesos de oveja (2.8) que en quesos de cabra y vaca (3.8 y 5.2). La relación n6/n3 y el índice trombogénico fueron menores en quesos chilenos que en quesos importados de Europa. El perfil de AG de quesos puede ser usado para diferenciar entre especies animales de las cuales proviene el queso y hasta cierto grado, el origen geográfico, ofreciendo indicios sobre el tipo de alimento y sistema productivo animal del cual provienen los quesos.

PALABRAS CLAVE: Ácidos grasos; Leche; Oveja; Queso

Citation/Cómo citar este artículo: Aguilar C, Toro-Mujica P, Vargas-Bello-Pérez E, Vera R, Ugalde C, Rodríguez S, Briones I. 2014. A comparative study of the fatty acid profiles in commercial sheep cheeses. Grasas Aceites 65 (4): e048. doi: http://dx.doi.org/10.3989/gya.0460141.

Copyright: (C) 2014 CSIC. This is an open-access article distributed under the terms of the Creative Commons Attribution-Non Commercial (by-nc) Spain 3.0 Licence. 


\section{INTRODUCTION}

In Chile there has been a significant growth in cheese production (ODEPA, 2012) and at the same time, there has been an incipient market for sheep cheese because it is considered a gourmet product whose production is expected to increase in the forthcoming years. In Chile, cardiovascular diseases are the leading cause of death among adults and the prevalence of cardiovascular risk factors is similar to that of European and North American populations (Bunout and Escobar, 2000). In the last decade, consumers have become more concerned about the fat content of dairy products and this has led to the development of different nutritional strategies to improve the FA composition of dairy products such as cheese (Vera et al., 2009; Toro-Mujica et al., 2011). Producing cheese with an improved fatty acid (FA) composition could significantly increase economic returns to farmers (Vera et al., 2009). Ruminant cheeses have some FA that have beneficial effects on human health such as vaccenic (VA; C18:1t11) and conjugated linoleic acids (CLA; C18:2 c9, t11) (Aldai et al., 2013). It has been demonstrated that the modulation of dairy ewe diets (Vargas-Bello-Pérez et al., 2013 a,b) results in sheep cheese with reduced atherogenic and thrombogenic indices and low saturated FA contents.

The milk fatty acid profile of ruminants can be affected by different factors such as animal species, lactation stages, feeding, and genetics (VargasBello-Pérez and Garnsworthy, 2013). Cheese fat from dairy ewes is characterized by high concentrations of FA made-up with 6-10 atoms of carbon (Partidário et al., 2008). Also, compared to bovines and goats, the CLA contents in sheep milk are greater (Shingfield et al., 2010).

Given that sheep cheese has fatty acids that may have positive effects on human health and its production could signify economic profits, the objective of the present study is to analyze the FA profile of commercial sheep cheese in Chile. The results could become the basis for developing benchmarking tools and strategies aiming at improving the nutritional characteristics of sheep cheese.

\section{MATERIALS AND METHODS}

\subsection{Cheese samples}

Fifty-eight cheeses were collected from supermarkets of 5 different Chilean cities (Santiago, Rancagua, Melipilla, Viña del Mar and Puerto Natales) including 34 sheep cheeses, 7 from goat's milk, 11 from cow's milk, 4 from a mixture of sheep, goat and cow's milk and 2 from a mixture of sheep and cow's milk. The sheep cheeses were produced in Chile (23 cheeses) and imported from France ( 2 cheeses) and Spain ( 9 cheeses). After collection, the cheeses were cut in four sections at which time two cores of each cheese were obtained and stored in re-sealable bags at $-80{ }^{\circ} \mathrm{C}$ for one month until further analysis.

\subsection{Fatty acid analysis}

Two cores of each cheese were used for the FA analysis. The lipids from the cheese were extracted according to a chloroform/methanol $(2: 1, \mathrm{v} / \mathrm{v})$ by Folch et al. (1957) method and methylated with the modifications of Sukhija and Palmquist (1988) using hexane as an organic solvent instead of benzene. Analyses of fatty acid methyl esters (FAME) were performed using a gas chromatograph (GC; Shimadzu Scientific Instruments AOC20s, Columbia, MD, USA) equipped with a flame ionization detector, an autoinjector and an Rtx column $(30 \mathrm{~m} \times 0.32 \mathrm{~mm} \times 0.20 \mu \mathrm{m}$ column$)$. The GC conditions were similar to those reported by VargasBello-Pérez et al. (2013b). FA peaks were identified by using two FAME standards (GLC 60; Nu-CheckPrep, Elysan, MN, USA), and the Food Industry 37 FAME mix, 35077 Restek Co, Bellefonte, PA, USA). C18:1 trans isomers were detected by comparing retention times as reported by Ledoux et al. (2000).

\subsection{Statistical analysis}

The samples were assigned to four groups: cow, sheep, goat and mixtures. The samples were analyzed using ANOVA and multiple comparisons of means. In order to determine which FA was responsible for the differentiation between cheeses that were made from different animal species and geographical origin a multivariate analysis was carried out using a correlation matrix between individual FA to discard those that showed very high correlations $(r=>0.9)$ as well as those without correlations. Bartlett's test of sphericity was applied to examine the hypothesis that the variables were uncorrelated in the population and the Kaiser-Meyer-Olkin index was used to measure sampling adequacy. Hierarchical clustering was then performed and a discriminant analysis was used to verify the extent to which samples were correctly assigned to the clusters identified in the previous analysis. To check for possible differences among cheeses associated with country of origin (Chile, Spain and France) an individual analysis of variance and multiple means comparison were performed. The SPSS statistical software for Windows was used (version 15.0.0; SPSS Inc., Chicago IL, USA).

\section{RESULTS AND DISCUSSION}

\subsection{Fatty acid profile of cheeses}

From the cheese samples analyzed, only $\mathrm{C} 17: 0$ was not different among animal species (Table 1). Regardless of cheese type, C10:0, C14:0, C16:0, 
A comparative study of the fatty acid profiles in commercial sheep cheeses $\bullet 3$

TABLE 1. Fatty acid profile (mean \pm standard deviation) of cheese from different animal species $\left(\mathrm{g} \cdot 100 \mathrm{~g}^{-1}\right.$ of total FAME)

\begin{tabular}{|c|c|c|c|c|c|}
\hline Fatty acid & $\begin{array}{c}\text { Cow } \\
(n=11)\end{array}$ & Sheep $(n=34)$ & $\begin{array}{c}\text { Goat } \\
(\mathrm{n}=7)\end{array}$ & Mixture $(n=6)$ & P-value \\
\hline $\mathrm{C} 4: 0$ & $1.32 \pm 0.15^{\mathrm{c}}$ & $1.18 \pm 0.17^{b}$ & $1.01 \pm 0.07^{\mathrm{a}}$ & $1.18 \pm 0.07^{\mathrm{b}}$ & 0.001 \\
\hline C6:0 & $1.08 \pm 0.05^{\mathrm{a}}$ & $1.36 \pm 0.19^{\mathrm{bc}}$ & $1.44 \pm 0.11^{\mathrm{c}}$ & $1.21 \pm 0.11^{\mathrm{ab}}$ & $<0.001$ \\
\hline C8:0 & $0.81 \pm 0.05^{\mathrm{a}}$ & $1.62 \pm 0.29^{\mathrm{c}}$ & $2.06 \pm 0.24^{\mathrm{d}}$ & $1.29 \pm 0.25^{\mathrm{b}}$ & $<0.001$ \\
\hline C10:0 & $2.17 \pm 0.23^{\mathrm{a}}$ & $5.92 \pm 1.06^{\mathrm{c}}$ & $8.44 \pm 1.22^{\mathrm{d}}$ & $4.47 \pm 1.07^{\mathrm{b}}$ & $<0.001$ \\
\hline $\mathrm{C} 12: 0$ & $2.93 \pm 0.38^{\mathrm{a}}$ & $3.99 \pm 0.59^{\mathrm{b}}$ & $4.46 \pm 0.82^{\mathrm{b}}$ & $3.18 \pm 0.54^{\mathrm{a}}$ & $<0.001$ \\
\hline $\mathrm{C} 14: 0$ & $11.1 \pm 0.62^{\mathrm{ab}}$ & $11.43 \pm 1.15^{\mathrm{b}}$ & $10.53 \pm 0.82^{\mathrm{a}}$ & $10.23 \pm 1.01^{\mathrm{a}}$ & 0.028 \\
\hline $\mathrm{C} 14: 1 \mathrm{c} 9$ & $1.62 \pm 0.17^{\mathrm{c}}$ & $0.84 \pm 0.13^{\mathrm{b}}$ & $0.49 \pm 0.04^{\mathrm{a}}$ & $0.91 \pm 0.22^{\mathrm{b}}$ & $<0.001$ \\
\hline C15:0 & $1.35 \pm 0.25^{\mathrm{b}}$ & $1.34 \pm 0.25^{\mathrm{b}}$ & $1.01 \pm 0.12^{\mathrm{a}}$ & $1.05 \pm 0.21^{\mathrm{a}}$ & 0.001 \\
\hline $\mathrm{C} 16: 0$ & $31.84 \pm 3.08^{\mathrm{b}}$ & $28.55 \pm 2.33^{\mathrm{a}}$ & $29.88 \pm 1.1^{\mathrm{ab}}$ & $30.9 \pm 1.87^{\mathrm{b}}$ & $<0.001$ \\
\hline C16:1c9 & $2.01 \pm 0.14^{\mathrm{c}}$ & $1.4 \pm 0.39^{\mathrm{b}}$ & $0.74 \pm 0.25^{\mathrm{a}}$ & $1.37 \pm 0.36^{\mathrm{b}}$ & $<0.001$ \\
\hline $\mathrm{C} 17: 0$ & $0.73 \pm 0.12$ & $0.76 \pm 0.14$ & $0.69 \pm 0.10$ & $0.69 \pm 0.17$ & 0.418 \\
\hline $\mathrm{C} 17: \ln 3(\mathrm{c} 10)$ & $0.34 \pm 0.05^{\mathrm{b}}$ & $0.36 \pm 0.07^{\mathrm{ab}}$ & $0.29 \pm 0.07^{\mathrm{a}}$ & $0.32 \pm 0.07^{\mathrm{ab}}$ & 0.047 \\
\hline C18:0 & $12.12 \pm 1.39^{\mathrm{ab}}$ & $11.64 \pm 1.91^{\mathrm{ab}}$ & $11.08 \pm 1.33^{\mathrm{a}}$ & $13.12 \pm 1.53^{\mathrm{b}}$ & 0.159 \\
\hline $\mathrm{C} 18: 1 \mathrm{t}$ & $3.36 \pm 1.65^{\mathrm{ab}}$ & $3.77 \pm 1.21^{\mathrm{b}}$ & $2.47 \pm 1.26^{\mathrm{a}}$ & $2.7 \pm 0.65^{\mathrm{ab}}$ & 0.050 \\
\hline $\mathrm{C} 18: \ln 9 \mathrm{c}$ & $22.52 \pm 1.52^{\mathrm{b}}$ & $19.64 \pm 1.92^{\mathrm{a}}$ & $19.75 \pm 2.93^{\mathrm{a}}$ & $22.68 \pm 1.35^{\mathrm{b}}$ & $<0.001$ \\
\hline $\mathrm{C} 18: 2 \mathrm{n} 6(\mathrm{t} 9,12)$ & $0.41 \pm 0.07^{\mathrm{a}}$ & $0.58 \pm 0.13^{\mathrm{b}}$ & $0.52 \pm 0.23^{\mathrm{ab}}$ & $0.41 \pm 0.10^{\mathrm{a}}$ & 0.001 \\
\hline $\mathrm{C} 18: 2 \mathrm{n} 6(\mathrm{c} 9,12)$ & $2.15 \pm 0.41^{\mathrm{a}}$ & $2.22 \pm 0.42^{\mathrm{a}}$ & $3.22 \pm 0.43^{\mathrm{b}}$ & $2.2 \pm 0.33^{\mathrm{a}}$ & $<0.001$ \\
\hline $\mathrm{C} 18: 3 \mathrm{n} 6(\mathrm{c} 6,9,12)$ & $0.06 \pm 0.07^{\mathrm{a}}$ & $0.34 \pm 0.07^{\mathrm{c}}$ & $0.24 \pm 0.07^{\mathrm{b}}$ & $0.29 \pm 0.08^{\mathrm{bc}}$ & $<0.001$ \\
\hline $\mathrm{C} 18: 3 \mathrm{n} 3(\mathrm{c} 9,12,15)$ & $0.63 \pm 0.27^{\mathrm{a}}$ & $0.96 \pm 0.34^{\mathrm{b}}$ & $0.77 \pm 0.47^{\mathrm{ab}}$ & $0.55 \pm 0.33^{\mathrm{a}}$ & 0.009 \\
\hline $\mathrm{C} 20: \ln 9(\mathrm{c} 11)$ & $1.26 \pm 0.67^{\mathrm{ab}}$ & $1.49 \pm 0.59^{\mathrm{b}}$ & $0.74 \pm 0.29^{\mathrm{a}}$ & $0.86 \pm 0.29^{\mathrm{a}}$ & 0.005 \\
\hline Others & $0.95 \pm 0.15^{\mathrm{a}}$ & $0.6 \pm 0.24^{\mathrm{b}}$ & $0.18 \pm 0.10^{\mathrm{a}}$ & $0.39 \pm 0.11^{\mathrm{a}}$ & $<0.001$ \\
\hline Short chain FA & $2.40 \pm 0.15$ & $2.53 \pm 0.33$ & $2.44 \pm 0.15$ & $2.39 \pm 0.05$ & 0.434 \\
\hline Medium chain FA & $5.91 \pm 0.65^{\mathrm{a}}$ & $11.53 \pm 1.89^{\mathrm{c}}$ & $14.96 \pm 2.06^{\mathrm{d}}$ & $8.93 \pm 1.75^{\mathrm{b}}$ & $<0.001$ \\
\hline Short + medium chain FA & $5.39 \pm 0.29^{\mathrm{a}}$ & $8.14 \pm 1.34^{\mathrm{b}}$ & $10.07 \pm 1.62^{\mathrm{c}}$ & $12.94 \pm 1.53^{\mathrm{d}}$ & $<0.010$ \\
\hline Long chain FA & $57.13 \pm 2.23^{\mathrm{b}}$ & $53.72 \pm 1.83^{\mathrm{a}}$ & $53.19 \pm 1.21^{\mathrm{a}}$ & $55.99 \pm 1.63^{\mathrm{b}}$ & $<0.001$ \\
\hline Saturated FA & $65.45 \pm 2.57^{\mathrm{a}}$ & $67.78 \pm 2.14^{\mathrm{b}}$ & $70.6 \pm 1.84^{\mathrm{c}}$ & $67.32 \pm 2.09^{\mathrm{ab}}$ & $<0.001$ \\
\hline Monounsaturated FA & $31.11 \pm 2.61^{\mathrm{c}}$ & $27.51 \pm 1.93^{\mathrm{b}}$ & $24.47 \pm 2.2^{\mathrm{a}}$ & $28.83 \pm 1.85^{\mathrm{b}}$ & $<0.001$ \\
\hline Polyunsaturated FA & $3.25 \pm 0.28^{\mathrm{a}}$ & $4.11 \pm 0.61^{\mathrm{b}}$ & $4.75 \pm 0.77^{\mathrm{c}}$ & $3.45 \pm 0.51^{\mathrm{a}}$ & 0.009 \\
\hline PUFA n3 & $0.63 \pm 0.27^{\mathrm{a}}$ & $0.96 \pm 0.34^{\mathrm{b}}$ & $0.77 \pm 0.47^{\mathrm{ab}}$ & $0.55 \pm 0.33^{\mathrm{a}}$ & $<0.001$ \\
\hline PUFA n6 & $2.62 \pm 0.43^{\mathrm{a}}$ & $3.15 \pm 0.49^{\mathrm{b}}$ & $3.98 \pm 0.46^{\mathrm{c}}$ & $2.9 \pm 0.37^{\mathrm{ab}}$ & $<0.001$ \\
\hline PUFA n6/ PUFA n3 & $5.17 \pm 2.82^{\mathrm{ab}}$ & $3.79 \pm 1.81^{\mathrm{a}}$ & $6.09 \pm 1.79^{\mathrm{b}}$ & $6.45 \pm 2.78^{\mathrm{b}}$ & $<0.007$ \\
\hline PUFA/SFA & $0.049 \pm 0.005^{\mathrm{a}}$ & $0.061 \pm 0.009^{\mathrm{b}}$ & $0.067 \pm 0.011^{\mathrm{b}}$ & $0.051 \pm 0.009^{\mathrm{a}}$ & $<0.001$ \\
\hline Atherogenicity index ${ }^{1}$ & $2.33 \pm 0.35$ & $2.49 \pm 0.35$ & $2.63 \pm 0.29$ & $2.34 \pm 0.32$ & 0.226 \\
\hline Thrombogenic index ${ }^{2}$ & $2.94 \pm 0.44^{\mathrm{ab}}$ & $2.81 \pm 0.28^{\mathrm{a}}$ & $3.1 \pm 0.28^{\mathrm{b}}$ & $3.09 \pm 0.34^{\mathrm{ab}}$ & 0.070 \\
\hline
\end{tabular}

Short-chain FA = C4:0-C6:0; Medium-chain FA = C8:0-C12:0; Short- + medium- chain FA = C4:0-C10:0; Long-chain FA= $\geq$ C14:0; Means in the same row with different superscripts are different $(\mathrm{P}<0.05)$. ${ }^{1}$ Atherogenicity index $=[(12: 0+4(14: 0)+16: 0]$ $/[(\mathrm{n} 6+\mathrm{n} 3)$ PUFA $+18: 1+\Sigma$ MUFA $]$ (Ulbricht and Southgate, 1991); ${ }^{2}$ Thrombogenic index $=(14: 0+16: 0+18: 0) /[(0.5 \times 18: 1)$ $+0.5($ MUFA $)+0.5($ n6PUFA $)+3($ n3PUFA $)+(n 3 P U F A / n 6 P U F A)](U l b r i c h t$ and Southgate, 1991)

C18:0, C18:1 t11 and C18:1c9 represented around $78 \%$ of the total FA, and these results agree with those reported previously (Partidário et al., 2008; Walther et al., 2008). As reported by Park et al. (2007), sheep and goat cheese contained higher contents of caproic (C6:0), caprylic (C8:0), capric (C10:0) and lauric (C12:0) acids than cow cheese. Fatty acids which are formed by 4 to 14 carbons arise chiefly from de novo synthesis whereas FAs with more than 16 carbons are derived from the uptake of circulating lipids. Ruminants utilize acetate produced by the ruminal fermentation of carbohydrates (contained in dietary fiber) as the major carbon source (Bauman and Griinari, 2003). Fatty acids with less than 12 carbons are associated with the typical flavors of small ruminant cheese and 
can also be used to detect mixtures of milk from different species (Park et al., 2007).

Compared with cow and goat, sheep cheese had higher contents of C18:1 trans isomers. In ruminant fat, vaccenic acid (VA; C18:1 t11) is the most common C18:1 trans isomer accounting for 60 to $80 \%$ of the total trans FA (Vargas-Bello-Pérez and Garnsworthy, 2013). VA can be converted to C18:2 c9, t11 (rumenic acid; RA) through the action of stearoyl coenzyme A desaturase and it has been estimated that $20 \%$ of VA can be converted to RA in humans. The RA has been identified as anticarcinogenic, anti-atherosclerotic, antioxidant, and immunomodulator (Young et al., 2013). The C18:1 trans isomer contents in sheep cheese are similar to those reported in Italian (Nudda et al., 2005) and Spanish (Luna et al., 2005) cheeses. This may be due to the feeding practices.It is possible that those cheeses came from farms where the sheep were fed with fresh pastures or supplemented with oilseeds. When pasture inclusion increases in the total diet, linear increases in $\mathrm{C} 18: 3 \mathrm{n} 3, \mathrm{C} 18: 1 \mathrm{t} 11$ and $\mathrm{C} 18: 2$ c9t11 and decreases in C10:0-C16:0 are observed (Chilliard et al., 2007). On the other hand, oilseeds are rich sources of polyunsaturated fatty acids (PUFA), which, after being biohydrogenated in the rumen, can increase the concentrations of health promoting FA such as linolenic $(\mathrm{C} 18: 3 \mathrm{n} 3)$ and rumenic acids (Zhang et al., 2006).

Interestingly, the $\mathrm{C} 18: 1$ trans isomers and $\mathrm{C} 18: 3 \mathrm{n} 3$ contents were higher in Chilean sheep cheese than in the French and Spanish cheese (Table 2). As mentioned before, those FA can be improved when the ewe diet is based mostly on pastures. In Chile, sheep production is based largely on grazing systems, however, in Spain for example, sheep cheese is produced throughout the year leading to an intensification of reproductive management, and a reduction in grazing periods (Riedel et al., 2007). This type of system results in a substitution of on-farm natural resources (forages and pastures) with external inputs (conserved forages and concentrates) (Vera et al., 2009). No differences were observed between French and Spanish sheep cheese so it is possible that these countries have similar conditions among their production systems including feeding, breeds and level of intensification of farm management (Riedel et al., 2007).

\subsection{Nutritional value of total lipids in cheeses}

Nutritional recommendations are based on different ratios such as PUFA n6/ PUFA n3 and PUFA/SFA; these values are used to evaluate the nutritional value of fat for human consumption. The values for PUFA/SFA found in our cheese samples were below the recommended amount (above 0.45 ) for the human diet whereas only the values for sheep cheese were below the recommended level (less than 4.0) for the PUFA n6/PUFA $n 3$ ratio (British Department of Health, 1994). Compared to cow and goat, sheep cheese had a lower thrombogenic index and intermediate concentrations of SFA, MUFA and PUFA (Table 1). Saturated FA are known to increase the risk of coronary heart disease (CHD; Williams et al., 2000), on the contrary, milk MUFA and PUFA (e.g., C18:2 c9, t11) can reduce the risk of CHD and prevent some types of cancer (Mohammadzadeh et al., 2013). However, there is a lack of scientific evidence that other SFA such as C4:0-C10:0 (short- and medium- chain FA; SMFA) have an effect on blood cholesterol and CHD risk (Astrup et al., 2011). In this study, compared to cow and sheep, goat cheese had higher contents of SMFA.

From the human health perspective, in this study, Chilean sheep cheese could be considered healthier than those imported from Europe; this is supported by the higher PUFA n3 and lower PUFA n6 contents (consequently lower PUFA n6/ PUFA n3 ratio) found in the Chilean sheep cheese (Table 2). The PUFA n 3 play an important role in the prevention and control of coronary artery disease, hypertension, diabetes, arthritis, autoimmune disorders and cancer (Simopoulos, 2000).

\subsection{Multivariate analysis}

The correlation matrix of FA discarded C4:0, C6:0, C18:0 and C20:1n9 (c11). The principal component analysis (PCA) carried out on the 16 remaining FA resulted in 4 principal components (PCs) which explained 0.84 of the overall variance in the data. PC1 and PC2 explained 0.34 and 0.28 of the variation in FA contents (Table 3). The KMO index was 0.62, whereas the Bartlett's test of sphericity showed the suitability $(\mathrm{P}<0.001)$ of those variables selected for analysis.

Three groups were found after PCA was carried out in order to obtain data clusters related to the fatty acid profiles of the cheeses. Group I was formed by 26 samples from which 23 were Chilean sheep cheeses, 2 were Chilean mixture cheeses (90\% sheep and 10\% cow milk) and 1 Chilean goat cheese. Group II was composed of 13 samples from which 11 were Chilean cow cheeses and 2 were Spanish mixture cheeses (proportion of milks was not found in the label). Finally, Group III was formed by 19 samples from which 9 were Spanish sheep cheeses, 2 were French sheep cheeses, 2 were Spanish mixture cheeses and 6 were Chilean goat cheeses.

PC1 consisted of the typical FA that can be found in the milk of small ruminants (C8:0 and C10:0) (Partidário et al., 2008) whereas C14:1c9 and $\mathrm{C} 16: 1 \mathrm{c} 9$ are usually detected in the milk and cheeses of cows (O’Donnell et al., 2010). Figure 1 shows a clear difference among animal species particularly 
TABLE 2. Fatty acid profile (mean \pm standard deviation) of sheep cheese from different geographical origins $\left(\mathrm{g} \cdot 100 \mathrm{~g}^{-1}\right.$ of total FAME)

\begin{tabular}{|c|c|c|c|c|}
\hline Fatty acid & Chile $(n=23)$ & France $(n=2)$ & Spain $(n=9)$ & P-value \\
\hline $\mathrm{C} 4: 0$ & $1.09 \pm 0.16^{\mathrm{a}}$ & $1.18 \pm 0.19^{\mathrm{ab}}$ & $1.32 \pm 0.10^{\mathrm{b}}$ & 0.003 \\
\hline C6:0 & $1.3 \pm 0.21^{\mathrm{a}}$ & $1.54 \pm 0.10^{\mathrm{a}}$ & $1.42 \pm 0.13^{\mathrm{a}}$ & 0.122 \\
\hline $\mathrm{C} 8: 0$ & $1.53 \pm 0.31$ & $1.94 \pm 0.19$ & $1.7 \pm 0.19$ & 0.087 \\
\hline $\mathrm{C} 10: 0$ & $5.61 \pm 1.13$ & $7.15 \pm 0.29$ & $6.23 \pm 0.71$ & 0.072 \\
\hline $\mathrm{C} 12: 0$ & $3.84 \pm 0.60$ & $4.67 \pm 0.07$ & $4.13 \pm 0.45$ & 0.090 \\
\hline $\mathrm{C} 14: 0$ & $11.6 \pm 1.25$ & $11.81 \pm 0.10$ & $10.85 \pm 0.64$ & 0.215 \\
\hline $\mathrm{C} 14: 1 \mathrm{c} 9$ & $0.92 \pm 0.09^{\mathrm{b}}$ & $0.69 \pm 0.01^{\mathrm{a}}$ & $0.7 \pm 0.06^{\mathrm{a}}$ & $<0.001$ \\
\hline C15:0 & $1.46 \pm 0.21^{\mathrm{b}}$ & $1.08 \pm 0.01^{\mathrm{a}}$ & $1.09 \pm 0.08^{\mathrm{a}}$ & $<0.001$ \\
\hline $\mathrm{C} 16: 0$ & $28.88 \pm 2.79$ & $28.25 \pm 0.55$ & $27.8 \pm 1.20$ & 0.527 \\
\hline $\mathrm{C} 16: 1 \mathrm{c} 9$ & $1.52 \pm 0.40$ & $1.3 \pm 0.02$ & $1.19 \pm 0.27$ & 0.090 \\
\hline $\mathrm{C} 17: 0$ & $0.8 \pm 0.15^{\mathrm{b}}$ & $0.66 \pm 0.02^{\mathrm{ab}}$ & $0.67 \pm 0.04^{\mathrm{a}}$ & 0.037 \\
\hline $\mathrm{C} 17: \ln 3(\mathrm{c} 10)$ & $0.39 \pm 0.07^{\mathrm{b}}$ & $0.29 \pm 0.04^{\mathrm{a}}$ & $0.30 \pm 0.02^{\mathrm{a}}$ & 0.001 \\
\hline C18:0 & $11.14 \pm 2.09$ & $12 \pm 0.47$ & $12.81 \pm 1.22$ & 0.093 \\
\hline C18:1t & $4.26 \pm 1.18^{\mathrm{b}}$ & $2.84 \pm 0.48^{\mathrm{ab}}$ & $2.95 \pm 0.59^{\mathrm{a}}$ & 0.007 \\
\hline $\mathrm{C} 18 \mathrm{~s} \ln 9 \mathrm{c}$ & $19.1 \pm 1.89^{\mathrm{a}}$ & $19.27 \pm 0.07^{\mathrm{ab}}$ & $21.38 \pm 1.14^{\mathrm{b}}$ & 0.007 \\
\hline $\mathrm{C} 18: 2 \mathrm{n} 6(\mathrm{t} 9,12)$ & $0.59 \pm 0.10$ & $0.41 \pm 0.08$ & $0.56 \pm 0.12$ & 0.075 \\
\hline $\mathrm{C} 18: 2 \mathrm{n} 6(\mathrm{c} 9,12)$ & $1.98 \pm 0.26^{\mathrm{a}}$ & $2.46 \pm 0.05^{\mathrm{b}}$ & $2.69 \pm 0.29^{\mathrm{b}}$ & $<0.001$ \\
\hline C18:3n6(c6,9,12) & $0.34 \pm 0.08$ & $0.3 \pm 0.03$ & $0.35 \pm 0.05$ & 0.628 \\
\hline $\mathrm{C} 18: 3 \mathrm{n} 3(\mathrm{c} 9,12,15)$ & $1.1 \pm 0.25^{\mathrm{b}}$ & $0.78 \pm 0.09^{\mathrm{ab}}$ & $0.59 \pm 0.14^{\mathrm{a}}$ & $<0.001$ \\
\hline $\mathrm{C} 20: \ln 9(\mathrm{c} 11)$ & $1.86 \pm 0.42^{\mathrm{b}}$ & $0.93 \pm 0.19^{\mathrm{a}}$ & $0.83 \pm 0.15^{\mathrm{a}}$ & $<0.001$ \\
\hline Others & $0.68 \pm 0.24^{\mathrm{b}}$ & $0.48 \pm 0.05^{\mathrm{ab}}$ & $0.43 \pm 0.13^{\mathrm{a}}$ & 0.014 \\
\hline Short chain FA & $2.39 \pm 0.33^{\mathrm{a}}$ & $2.72 \pm 0.08^{\mathrm{ab}}$ & $2.74 \pm 0.23^{\mathrm{a}}$ & 0.019 \\
\hline Medium chain FA & $10.98 \pm 1.97$ & $13.76 \pm 0.55$ & $12.05 \pm 1.33$ & 0.070 \\
\hline Short + medium chain FA & $9.54 \pm 1.7$ & $10.67 \pm 1.09$ & $11.81 \pm 0.4$ & 0.050 \\
\hline Long chain FA & $53.88 \pm 2.03$ & $53.8 \pm 1.15$ & $53.22 \pm 1.49$ & 0.676 \\
\hline Saturated FA & $67.25 \pm 2.15$ & $70.27 \pm 0.68$ & $68.01 \pm 1.21$ & 0.097 \\
\hline Monounsaturated FA & $28.05 \pm 1.93$ & $25.30 \pm 0.63$ & $27.37 \pm 1.06$ & 0.091 \\
\hline Polyunsaturated FA & $4.02 \pm 0.57$ & $3.95 \pm 0.10$ & $4.2 \pm 0.48$ & 0.678 \\
\hline PUFA n3 & $1.09 \pm 0.25^{\mathrm{b}}$ & $0.78 \pm 0.10^{\mathrm{ab}}$ & $0.59 \pm 0.14^{\mathrm{b}}$ & $<0.001$ \\
\hline PUFA n6 & $2.92 \pm 0.36^{\mathrm{a}}$ & $3.17 \pm 0.03^{\mathrm{ab}}$ & $3.61 \pm 0.37^{\mathrm{b}}$ & $<0.001$ \\
\hline PUFA n6/ PUFA n3 & $2.76 \pm 0.61^{\mathrm{a}}$ & $4.1 \pm 0.51^{\mathrm{b}}$ & $6.41 \pm 1.27^{\mathrm{c}}$ & $<0.001$ \\
\hline PUFA/SFA & $0.059 \pm 0.009$ & $0.056 \pm 0.002$ & $0.062 \pm 0.008$ & 0.703 \\
\hline Atherogenicity index ${ }^{1}$ & $2.49 \pm 0.37$ & $2.74 \pm 0.1$ & $2.39 \pm 0.17$ & 0.380 \\
\hline Thrombogenic index ${ }^{2}$ & $2.71 \pm 0.25^{\mathrm{a}}$ & $3.09 \pm 0.18^{\mathrm{b}}$ & $2.96 \pm 0.19^{\mathrm{b}}$ & 0.019 \\
\hline
\end{tabular}

Short-chain FA=C4:0-C6:0; Medium-chain FA=C8:0-C12:0; Short- + medium- chain FA=C4:0-C10:0; Long-chain FA = $\geq$ C14:0; ${ }_{a, b, c}$ Means in the same row with different superscripts are different $(\mathrm{P}<0.05)$. ${ }^{1}$ Atherogenicity index $=[(12: 0+4(14: 0)+16: 0]$ $/[(\mathrm{n} 6+\mathrm{n} 3) \mathrm{PUFA}+18: 1+\Sigma$ MUFA $]$ (Ulbricht and Southgate, 1991); ${ }^{2}$ Thrombogenic index $=(14: 0+16: 0+18: 0) /[(0.5 \times 18: 1)$

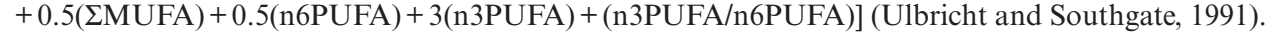

between Groups I and II. PC2 comprised C16:0, $\mathrm{C} 18: 1 \mathrm{t}, \mathrm{C} 18: 3 \mathrm{n} 3$ and $\mathrm{C} 18: 2 \mathrm{n} 6$, and therefore, the cheese in this PC may have a high MUFA/SFA ratio. Group I (mainly Chilean cheeses) had higher proportions of these FA.

The different data clusters obtained in this study showed that some FA vary depending on animal species, however, there are some confounding factors related to the type of feed, production system and breed of animals (Carta et al., 2008). For example, in Group III, where most of the European cheeses were grouped, most of the production systems may be intensive and their feeding management relies on high-concentrate diets (Sanz Sampelayo et al., 2007). 
TABle 3. Principal component (PC) analysis related to the fatty acid profile of cheese

\begin{tabular}{cclc}
\hline PC & Eigenvalue & \multicolumn{1}{c}{ Variables } & Correlation \\
\hline 1 & 5,1 & $\mathrm{C} 8: 0$ & 0,90 \\
& $33,7^{1}$ & $\mathrm{C} 10: 0$ & 0,92 \\
& $(33,7)^{2}$ & $\mathrm{C} 14: 1 \mathrm{c} 9$ & $-0,94$ \\
& & $\mathrm{C} 16: 1 \mathrm{c} 9$ & $-0,85$ \\
2 & 4,1 & $\mathrm{C} 16: 0$ & $-0,67$ \\
& 27,5 & $\mathrm{C} 18: 1 \mathrm{t}$ & 0,92 \\
& $(61,2)$ & $\mathrm{C} 18: 2 \mathrm{n} 6(\mathrm{t} 9,12)$ & 0,72 \\
& & $\mathrm{C} 18: 3 \mathrm{n} 3(\mathrm{c} 9,12,15)$ & 0,76 \\
3 & 2,0 & $\mathrm{C} 15: 0$ & 0,74 \\
& 13,1 & $\mathrm{C} 17: 0$ & 0,88 \\
& $(74,3)$ & $\mathrm{C} 17: 1 \mathrm{n} 3(\mathrm{c} 10)$ & 0,91 \\
4 & 1,4 & $\mathrm{C} 14: 0$ & 0,93 \\
& 9,3 & $\mathrm{C} 18: 1 \mathrm{n} 9 \mathrm{c}$ & $-0,81$ \\
& $(83,6)$ & & \\
\hline
\end{tabular}

${ }^{1}$ Proportion of variance explained; ${ }^{2}$ Variance accumulated.
These particular characteristics of production systems, animals, feedstuffs, etc., are closely related to the organoleptic characteristics of cheese that lead to the creation of the Protected Denomination of Origin (PDO) or Protected Geographical Identification (PGI) regimes (Martínez et al., 2011) and therefore become useful tools for creating strategies aiming at improving the nutritional characteristics of sheep cheese in Chile.

\section{CONCLUSIONS}

The results indicated that the FA profiles of Chilean cheese were desirable from a human health standpoint. The fatty acid profile of cheese can be used to differentiate the animal species from which the cheese is made and to some extent the geographical origin that may give some insights into animal feed and production management. The data from this study could be used to develop benchmark tools and strategies aiming at improving the nutritional characteristics of sheep cheese.

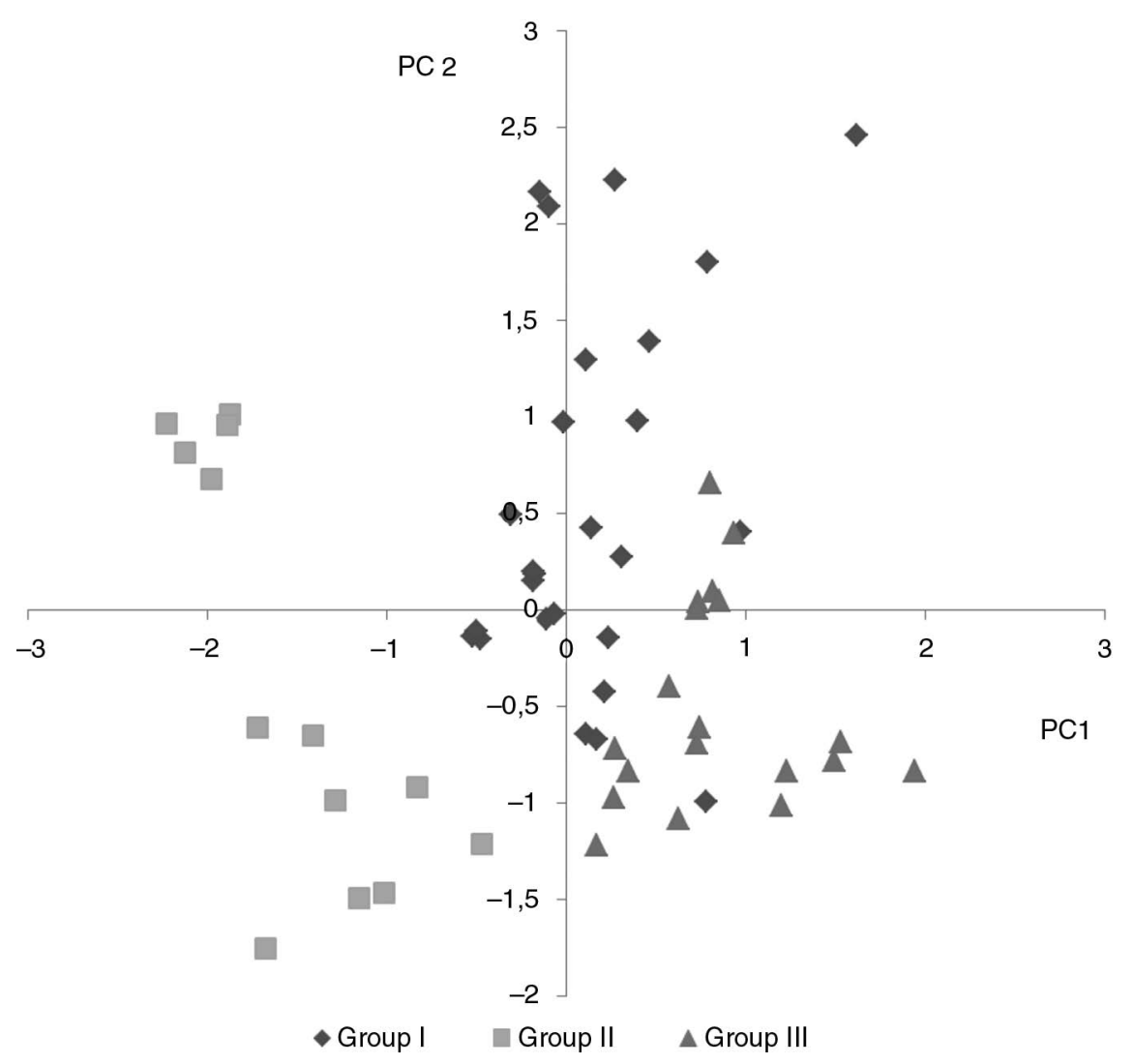

FIGURE 1. Positioning of the cheeses according to the scores obtained for PC 1 and PC 2.

Three groups were found after PCA was carried out in order to obtain data clusters related to the fatty acid profiles of the cheese. Group I: 26 samples from which 23 were Chilean sheep cheeses, 2 were Chilean mixture cheeses ( $90 \%$ sheep and $10 \%$ cow milk) and 1 Chilean goat cheese. Group II: 13 samples from which 11 were Chilean cow cheeses and 2 were Spanish mixture cheeses (proportion of milks was not found in the label). Group III: 19 samples from which 9 were Spanish sheep cheeses, 2 were French sheep cheeses, 2 were Spanish mixture cheeses and 6 were Chilean goat cheeses. 


\section{ACKOWLEDGEMENTS}

This study was supported by a research grant from FIA PYT-2008-0213 (Fondo de Innovación Agraria, Ministerio de Agricultura, Chile).

\section{REFERENCES}

Aldai N, de Renobales M, Barron LJR, Kramer JKG. 2013. What are the trans fatty acids issues in foods after discontinuation of industrially produced trans fats? Ruminant products, vegetable oils, and synthetic supplements. Eur. J. Lipid Sci. Tech. 115, 1378-1401. http://dx.doi.org/10.1002/ ejlt.201370029.

Astrup A, Dyerberg J, Elwood P, Hermansen K, Hu FB, Jakobsen MU, Kok FJ, Krauss RM, Lecerf JM, LeGrand P, Nestel P, Riserus U, Sanders T, Sinclair A, Stender S, Tholstrup T, Willett WC. 2011. The role of reducing intakes of saturated fat in the prevention of cardiovascular disease: where does the evidence stand in 2010? Am. J. Clin. Nutr. 93: 684-688. http://dx.doi.org/10.3945/ajen.110.004622.

Bauman DE, Griinari JM. 2003. Nutritional regulation of milk fat synthesis. Annu. Rev. Nutr. 23, 203-227. http:// dx. doi.org/10.1146/annurev.nutr.23.011702.073408.

British Department of Health. 1994. Nutritional aspects of cardiovascular disease. Report on Health and Social Subjects $\mathrm{N}^{\circ}$ 46, HMSO, London, UK, 1994.

Bunout D, Escobar E. 2000. Prevención de enfermedades cardiovasculares: ¿deben aplicarse los mismos criterios en América Latina que en Europa y Norte América? Rev. Esp. Cardiol. $\mathbf{5 3}, 889-895$

Carta A, Casu S, Usai MG, Addis M, Fiori M, Fraghí A, Miari S, Mura L, Piredda G, Schibler L, Sechi T, Elsen JM, Barillet F. 2008. Investigating the genetic component of fatty acid content in sheep milk. Small Ruminant Res. 79, 22-28. http://dx.doi.org/10.1016/j.smallrumres.2008.07.015.

Chilliard Y, Glasser F, Ferlay A, Bernard L, Rouel J, Doreau M. 2007. Diet, rumen biohydrogenation and nutritional quality of cow and goat milk fat. Eur. J. Lipid Sci. Technol. 109, 828-855. http://dx.doi.org/10.1002/ejlt.200700080.

Folch J, Lees M, Sloane-Stanley GH. 1957. A simple method for the isolation and purification of total lipids from animal tissues. J. Biol. Chem. 226, 497-509. PMid:13428781.

Ledoux M, Laloux L, Wolff RL. 2000. Analytical methods for determination of trans-C18 fatty acid isomers in milk fat. A review. Analusis, 28, 402-412. http://dx.doi.org/10.1051/ analusis:2000125.

Luna P, Fontecha J, Juarez M, de la Fuente MA. 2005. Changes in the milk and cheese fat composition of ewes fed commercial supplements containing linseed with special reference to the CLA content and isomer composition. Lipids 40, 445-454. http://dx.doi.org/10.1007/s11745-005-1403-3.

Martínez S, Franco I, Carballo J. 2011. Spanish goat and sheep milk cheeses. Small Ruminant Res. 101, 41-54. http:// dx doi.org/10.1016/j.smallrumres.2011.09.024

Mohammadzadeh M, FaramarziE, Mahdavi R, Nasirimotlagh B, Jafarabadi MA. 2013. Effect of conjugated linoleic acid supplementation on inflammatory factors and matrix metalloproteinase enzymes in rectal cancer patients undergoing chemoradiotherapy. Integr. Cancer Ther. 12, 496-502. http://dx.doi.org/10.1177/1534735413485417.

Nudda A, McGuire MA, Battacone G, Pulina G. 2005. Seasonal variation in conjugated linoleic acid and vaccenic acid in milk fat of sheep and its transfer to cheese and ricotta. J Dairy Sci. 88, 1311-1319. http://dx.doi.org/10.3168/jds. S0022-0302(05)72797-1.

O’Donnell AM, Spatny KP, Vicini JL, Bauman DE. 2010. Survey of the fatty acid composition of retail milk differing in label claims based on production management practices. J Dairy Sci. 93, 1918-1925. http://dx.doi.org/10.3168/ jds.2009-2799.
Office of Agrarian Studies and Policies (ODEPA). 2012. Estadísticas /por macro rubros/ lácteas. available at: http://www.odepa.gob.cl/jsp/lacteos/seil/seil_i5trp_enc.jsp. (accessed 10 December 2012).

Park YW, Juárez M, Ramos M, Haenlein GFW. 2007. Physicochemical characteristics of goat and sheep milk. Small Ruminant Res. 68, 88-113. http://dx.doi.org/10.1016/j. smallrumres.2006.09.013.

Partidário AM, Ribeiro JCS, Prates JAM. 2008. Fatty acid composition and nutritional value of fat in three PDO ewe's milk Portuguese cheeses. Dairy Sci. Technol. 88, 683-694. http://dx.doi.org/10.1051/dst:2008032.

Riedel JL, Casasus I, Bernues A. 2007. Sheep farming intensification and utilization of natural resources in a Mediterranean pastoral agro-ecosystem. Livest. Sci. 111, 153-163. http://dx.doi.org/10.1016/j.livsci.2006.12.013.

Sanz Sampelayo MR, Chilliard Y, Schmidely P, Boza J. 2007. Influence of type of diet on the fat constituents of goat and sheep milk. Small Ruminant Res. 68, 42-63. http://dx.doi. org/10.1016/j.smallrumres.2006.09.017.

Shingfield KJ, Bernard L, Leroux C, Chilliard Y. 2010. Role of trans fatty acids in the nutritional regulation of mammary lipogenesis in ruminants. Animal 4, 1140-1166. http:// dx.doi.org/10.1017/S1751731110000510.

Simopoulos AP. 2000. Human requirement for n-3 polyunsaturated fatty acids. Poultry Sci. 79, 961-970. http://dx.doi. org/10.1093/ps/79.7.961

Sukhija PS, Palmquist DL. 1988. Rapid method for determination of total fatty-acid content and composition of feedstuffs and feces. J. Agric. Food Chem. 36, 1202-1206. http:// dx.doi.org/10.1021/jf00084a019.

Toro-Mujica P, García A, Gómez-Castro AG, Acero R, Perea J, Rodríguez-Estévez V, Aguilar C, Vera R. 2011. Technical efficiency and viability of organic dairy sheep farming systems in a traditional area for sheep production in Spain. Small Ruminant Res. 100, 89-95. http://dx.doi. org/10.1016/j.smallrumres.2011.06.008.

Ulbricht TLV, Southgate DAT. 1991. Coronary Heart-Disease -7 Dietary Factors. Lancet 338, 985-992. http://dx.doi. org/10.1016/0140-6736(91)91846-M.

Vargas-Bello-Pérez E, Vera R, Aguilar C, Lira R, Peña I, Fernández J. 2013a. Feeding olive cake to ewes improves fatty acid profile of milk and cheese. Anim. Feed Sci. Tech. 184, 94-99. http://dx.doi.org/10.1016/j. anifeedsci.2013.05.016.

Vargas-Bello-Pérez E, Vera R, Aguilar C, Lira R, Peña I, Valenzuela A, Cerda H. 2013b. Effect of dietary inclusion of lampante olive oil on milk and cheese fatty acid profiles of ewes. Grasas Aceites 64, 295-303. http://dx.doi. org/10.3989/gya.108312.

Vargas-Bello-Pérez E, Garnsworthy PC. 2013 Trans fatty acids and their role in the milk of dairy cows. Ciencia Inv. Agr. 40, 449-473. http://dx.doi.org/10.4067/S071816202013000300001

Vera R, Aguilar C, Lira R. 2009. Differentiation of sheep milk and cheese based on quality and composition. Ciencia Inv. Agr. 36, 307-328. http://dx.doi.org/10.4067/ S0718-16202009000300001.

Walther B, Schmid A, Sieber R, Wehrmüller K. 2008. Cheese in nutrition and health. Dairy Sci. Technol. 88, 389-405. http://dx.doi.org/10.1051/dst:2008012.

Williams CM. 2000. Dietary fatty acids and human health. Ann. Zootech. 49, 165-180. http://dx.doi.org/10.1051/ animres:2000116.

Young JF, Therkildsen M, Ekstrand B, Che BN, Larsen MK, Oksbjerg N, Stagsted J. 2013. Novel aspects of health promoting compounds in meat. Meat Sci. 95, 904-911. http:// dx.doi.org/10.1016/i.meatsci.2013.04.036.

Zhang RH, Mustafa AF, Zhao X. 2006. Effects of feeding oilseeds rich in linoleic and linolenic fatty acids to lactating ewes on cheese yield and on fatty acid composition of milk and cheese. Anim. Feed Sci. Tech. 127, 220-233. http:// dx.doi.org/10.1016/j.anifeedsci.2005.09.001. 